\title{
THE ELECTRODISSOLUTION AND PASSIVATION OF MILD STEEL IN ALKALINE SULPHIDE SOLUTIONS*
}

\author{
R. C. Salvarezza, H. A. Videla and A. J. Arvía \\ Instituto de Investigaciones Fisicoquímicas Teóricas y Aplicadas INIFTA, División Electroguimica, \\ Sucursal 4, Casilla de Correo 16, (1900) La Plata, Argentina
}

\begin{abstract}
The electrodissolution and passivation of nild steel in alkaline sulphide solutions at $25^{\circ} \mathrm{C}$ is investigated by the use of steady state and transient electrochemical techniques and by scanning electron microscopy and energy dispersive X-ray analysis. The electrodissolution and passivation processes are explained by the initial competitive adsorption of $\mathrm{OH}^{-}, \mathrm{HS}^{-}$and $\mathrm{H}_{2} \mathrm{O}$ and the subsequent charge transfer and proton transfer processes involving the $\mathrm{OH}$ and $\mathrm{HS}$ adsorbed species. The former is responsible for the passivation of the metal by an oxide metal layer while the second species undergoes two different reactions yielding in one case a precipitated mackinawite film on the metal, which is a poorly protective layer, and in the other a soluble Fe(II) species which can be detected by chemical analysis. The contribution of the reactions starting from each adsorbed species depends on the HS$\mathrm{OH}^{-}$concentration ratio in the solution. The initiation of pitting on iron is also explained through the postulated reaction pattern.
\end{abstract}

\section{INTRODUCTION}

THE electrochemical behaviour of iron and steel in alkaline sulphide solutions has been studied both from a fundamental and a practical standpoint specially in relation with the corrosion problems in the pulp and paper industry. During the anodic polarization of iron in alkaline solutions containing sulphide, the potentiodynamic electrochemical profile is characterized at least by two anodic current peaks, the first one appearing in the active-passive transition potential range in free sulphide solutions. This current peak was assigned to the formation of a protective layer of ferrous sulphide on iron, ${ }^{1,2}$ although recent voltammetric studies ${ }^{3,4}$ showed that in this case the passive state of the metal is due to the presence of a defective oxide layer. The sulphide anions are apparently able to inhibit the oxide growth process on iron by a competitive process with the hydroxyl anions. This explains the decrease in height of the current peaks related to the oxide formation, which are observed in sodium hydroxide solutions during repetitive triangular potential scans. ${ }^{3}$ The presence of an oxide film containing a certain amount of sulphide species correlates with the interpretation of optical data related to the same electrochemical systems." However, polarization results obtained in hot alkaline sulphide solutions using a single linear potential scan ${ }^{6}$ show a remarkable increase in the anodic current associated with the passivation process with respect to that observed in sodium hydroxide solutions. The second anodic current peak occurring at potentials more positive than the activepassive transition potential range is absent in the alkaline solutions free from sulphide. For this reason several authors assigned the second anodic current contribution to the oxidation of sulphide ions. ${ }^{1,5,7,8}$ Conversely, this process has also been attributed to pitting, ${ }^{4}$ although there is no experimental evidence of any potential related to the

"Manuscript received 28 September 1981; in amended form 15 November 1981. 
breakdown of the passive film from the voltammetric and transient measurements. Otherwise, no data on the pit morphology and pit size distribution are available in the literature.

The present paper contributes to understand the electrodissolution and passivation of iron in alkaline sulphide solutions by envisaging the possible participation of competitive adsorption of anions on the metal in the initial stages of the electrochemical process and during the passive film growth.

\section{EXPERIMENTAL METHOD}

Specimens of $1020 \mathrm{SAE}$ steel of circular shape were axially included in a Teflon rod and machined in a lathe to obtain a disc metal electrode with an exposed apparent area of $0.2 \mathrm{~cm}^{2}$. The metal surface was firstly mechanically polished with a fine grained emery paper, and finally finished to a mirror surface with alumina paste of $0.3 \mu \mathrm{m}$ dia. Afterwards, each specimen was rinsed with A.R. acetone, with distilled water and finally dried in air at room temperature. A new electrode was used in each experiment. The electrolyte solutions were prepared with twice distilled water previously purged with purified nitrogen bubbling during $3 \mathrm{~h}$. A.R. chemicals $\left(\mathrm{Na}_{2} \mathrm{~S}^{9} \mathrm{H}_{2} \mathrm{O}\right.$ and $\left.\mathrm{NaOH}\right)$ were used to prepare the different electrolyte solutions. A stock solution of $10^{-2} \mathrm{M}$ sulphide solution (pH 12.00) was employed. Different solution $\mathrm{pH}$ values were adjusted by the addition of acetic acid. The electrolyte solutions were prepared just before each run. Electrochemical measurements were made in a conventional single compartment double wall Pyrex glass cell, at $25^{\circ} \mathrm{C}$. The potential of the working electrode was referred to a saturated calomel electrode (SCE), which was connected to the cell through a Luggin capillary tip arrangement and salt bridge to avoid impurification of the electrolyte from constituents of the reference electrode. A platinum wire was used as the counter electrode. Potentiodynamic $E / I$ curves started from $-1.00 \mathrm{~V}$ by changing the potential $10 \mathrm{mV}$ stepwise in the positive potential direction reading the current $1.5 \mathrm{~min}$ after the initiation of the potential step.

Experiments were also made using repetitive triangular potential scans (RTPS) within the switching potentials -1.4 and $0.0 \mathrm{~V}$. Both in the single sweep and in the RTPS runs, the working electrode was held at $-1.4 \mathrm{~V}$ during $5 \mathrm{~min}$ in order to electroreduce any surface species present on the specimen.

Microscopic observations were made on electrodes taken out of the cell and immediately washed with twice-distilled water saturated with nitrogen and later dried under nitrogen flux. Specimens exhibited a black loose corrosion product which was removed just by rinsing the electrode surface with distilled water and wiping it with a soft tissue. SEM microphotographs were taken with a Philips PSEM 500 equipment including an energy dispersive X-ray analysis system. For the weight loss measurements, rectangular $1020 \mathrm{SAE}$ steel electrodes with an exposed apparent area of $2 \mathrm{~cm}^{2}$ were used. The poorly adherent corrosion product was easily removed as mentioned above.

The chemical reactions between $\mathrm{Fe}, \mathrm{Fe}_{2} \mathrm{O}_{3}$ and $\mathrm{FeS}$ with sodium sulphide solutions were also investigated separately at $25^{\circ} \mathrm{C}$ using glass reactors intermittently stirred under a nitrogen atmosphere to avoid any possibility of sulphide oxidation. For this purpose, $10 \mathrm{~g}$ of $\mathrm{Fe}, \mathrm{Fe}_{2} \mathrm{O}_{3}$ and $\mathrm{FeS}$ as powders were placed in $300 \mathrm{ml}$ of the $10^{-2} \mathrm{M}$ sodium sulphide solution (pH 11.54). The soluble reaction products obtained after $240 \mathrm{~h}$ were filtered and the amount of dissolved iron ${ }^{9}$ was determined. lodimetric titrations were used to determine the total sulphide concentration. ${ }^{10}$ The visible-UVspectrum of the solution was also recorded with a conventional set-up.

\section{EXPERIMENTAL RESULTS AND INTERPRETATION}

Typical anodic polarization curves of mild steel in $10^{-2} \mathrm{M}$ sodium hydroxide (pH 11.54) (Fig. 1) exhibit firstly an active dissolution region comprised between the rest potential $\left(E_{\mathrm{r}}=-0.90 \mathrm{~V}\right)$ and $-0.82 \mathrm{~V}$ defining the first anodic current peak, then the active to passive transition region $(-0.82$ to $-0.72 \mathrm{~V})$, the second small anodic current peak $(-0.70$ to $-0.62 \mathrm{~V})$ and finally, the passive region which extends from $-0.62 \mathrm{~V}$ towards more positive potential values. On the other hand, the polarization curves obtained in $10^{-2} \mathrm{M}$ sodium sulphide ( $\left.\mathrm{pH} 11.54\right)$ show $E_{\mathrm{r}}$ values $(-0.98 \mathrm{~V})$ more negative than those of $10^{-2} \mathrm{M}$ sodium hydroxide and in the whole potential range the anodic current is one order of magnitude larger than for $10^{-2} \mathrm{M}$ sodium hydroxide. In the presence of sulphide the active-passive transition appears in the 


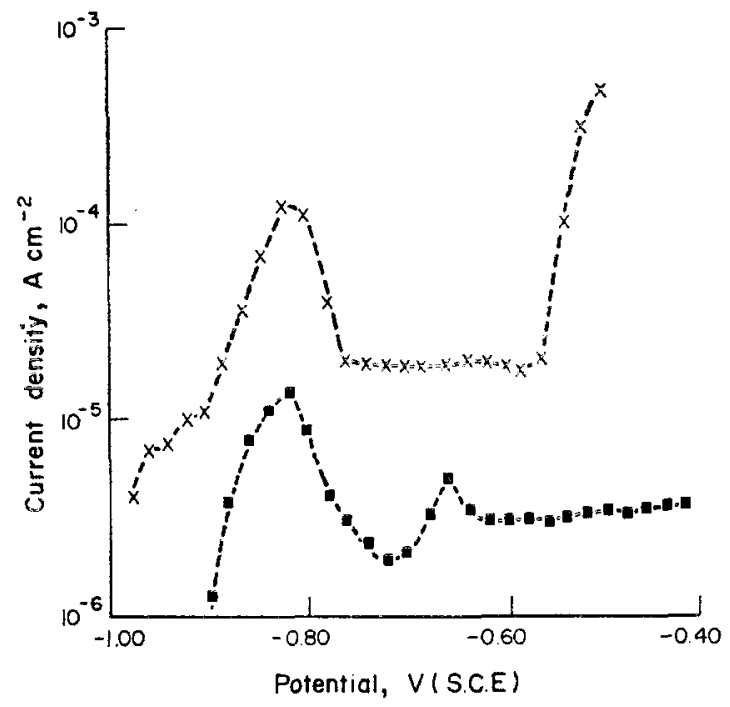

FIG. 1. Current/potential curves obtained for mild steel in $10^{-2} \mathrm{M} \mathrm{NaOH} \mathrm{pH} 11.54$ ( $\mathrm{a}$ ) and $10^{-2} \mathrm{M} \mathrm{Na}_{2} \mathrm{~S} \mathrm{pH} 11.54$ ( $($ ).

potential range already mentioned in free-sulphide solutions although the passive region covers only the -0.76 to $-0.58 \mathrm{~V}$ range. At potentials more positive than $-0.58 \mathrm{~V}$ a second abrupt current increase is observed which is probably associated with the second anodic current peak. In sodium hydroxide solutions both the first and second peaks have been assigned to the formation of $\mathrm{Fe}(\mathrm{OH})_{2}$ and to the formation of the $\mathrm{Fe}_{3} \mathrm{O}_{4}-\mathrm{Fe}_{2} \mathrm{O}_{3}$ film, respectively. ${ }^{3}$ The passivity of iron in sulphide solutions involves sulphide ions incorporated into the lattice of the $\mathrm{Fe}_{3} \mathrm{O}_{4}$ passive layer as it was demonstrated by electron diffraction and $\mathrm{X}$-ray energy analysis ${ }^{5}$ of anodic films formed at $100^{\circ}$. The inflection observed at $-0.90 \mathrm{~V}$ in the active region can be related to the prepassivation recently reported by Wensley and Charlton, ${ }^{6}$ which appears as an anodic current peak preceding the active-passive transition. This current peak was attributed to oxidation reactions involving sulphur containing species yielding either compounds in a higher oxidation state or an adsorbed layers of iron sulphide, through the electro-oxidation of the base metal.

The current relaxation at constant potential depends on whether the potential is fixed in the active, in the passive or in the transpassive region (Fig. 2). Thus, for $E:=$ - $0.90 \mathrm{~V}$ the high initial anodic current firstly decays, then goes through zero and finally becomes a cathodic current. In the -0.90 to $-0.64 \mathrm{~V}$ range the current decays from $10^{-5} \mathrm{~A} \mathrm{~cm}^{-2}$ to approx. $10^{-6} \mathrm{~A} \mathrm{~cm}^{-2}$. The current decay is faster as the potential step is more positive. However, when $E=-0.63 \mathrm{~V}$ the current decay exhibits a minimum and attains a nearly constant value equal to $10^{-4} \mathrm{~A} \mathrm{~cm}^{-2}$. But at $E$ $-0.60 \mathrm{~V}$ the current increases slowly but steadily reaching a plateau at $10^{-3} \mathrm{~A} \mathrm{~cm}^{-2}$ after exceeding $30 \mathrm{~min}$ from the instant the potential is switched on. Two different approaches were made to explain this anodic current increase. Thus, Bolmer assigned it to the oxidation of sulphide ions present on the metal surface yielding either free sulphur or a soluble polysulphide. ${ }^{1}$ Conversely, the deposition of sulphur according to 


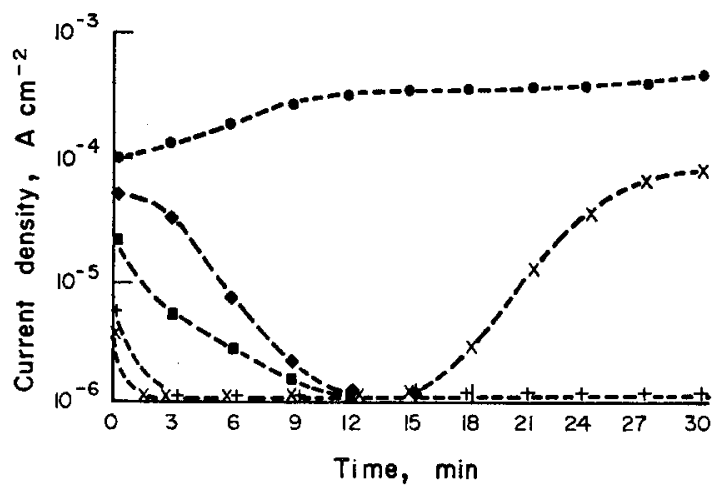

FIG. 2. Current/time plots at constant potential for mild steel electrodes in $10^{-2} \mathrm{M}$ $\mathrm{Na}_{2} \mathrm{~S}$ pH 11.54. $\mathrm{E}=-0.90(\diamond) ;-070(\Xi) ;-0.64(+) ;-0.62(\times) ;-0.60(\bullet)$.

Kaesche ${ }^{7}$ and Janik-Czachor ${ }^{8}$ occurs on top of a dual layer of $\mathrm{Fe}_{3} \mathrm{O}_{4}$ and $\mathrm{Fe}_{2} \mathrm{O}_{3}$. On the other hand, Tromans indicated that the marked current increase may be due to the oxidation of aqueous sulphide to $\mathrm{S}_{2} \mathrm{O}_{3}{ }^{2-},{ }^{5}$ a process which decreases accordingly to the sulphide content in the $\mathrm{Fe}_{3} \mathrm{O}_{4}$ lattice. Shoesmith et al. considered that the increase in current is related to the anodic dissolution of iron as a consequence of the breakdown of the passive film leading to pitting of the base metal. ${ }^{3}$ However, these interpretations are not fully supported either through microscopic observations or through any evidence of the appearance of a breakdown potential.

To clarify this point the specimens were held at a preset potential in the transpassive region using $10^{-2} \mathrm{M} \mathrm{Na}_{2} \mathrm{~S}$ solutions ( $\mathrm{pH}$ 11.54) and the macroscopic observations of these specimens made afterwards revealed the appearance of a thick black corrosion product on the electrode surface distributed as blister-like isolated spots. After washing and drying the electrode these spots appear as blown-up blisters. The rupture of the spots occurs along the periphery of the blister and there is a secondary outer area around the blister perimeter, ${ }^{11}$ where net localized corrosion of the metal occurs. The change of this area indicates the radial growth of the blister through the metal electrodissolution. The energy dispersive X-ray microanalysis of the blister shows that sulphur is localized in the region around the blister perimeter as a thick amorphous film which, according to the spectra, corresponds to amorphous iron sulphide. Its structure is probably related to that of mackinawite, a rich iron sulphide which has been described by Shoesmith et al..$^{4}$ and Tromans ${ }^{5}$ during the corrosion and passivation of iron in alkaline sulphide solutions. Conversely, only a negligible signal of sulphur is detected in the region outside the blister and in the secondary area. This suggests than an iron oxide rather than iron sulphide is present in those regions (Fig. 3).

Once the corrosion product has been removed, the microscopic observations of the sample shows crystallographic pits within the blister. These pits which are randomly distributed in the central region (Fig. 4a and 4 b) initially exhibit a net spike type geometry. From their size distribution it is concluded that they are formed through the progressive nucleation and growth of isolated pits. They initially appear in a preferred orientation and when their number is sufficiently large they coalesce into small 

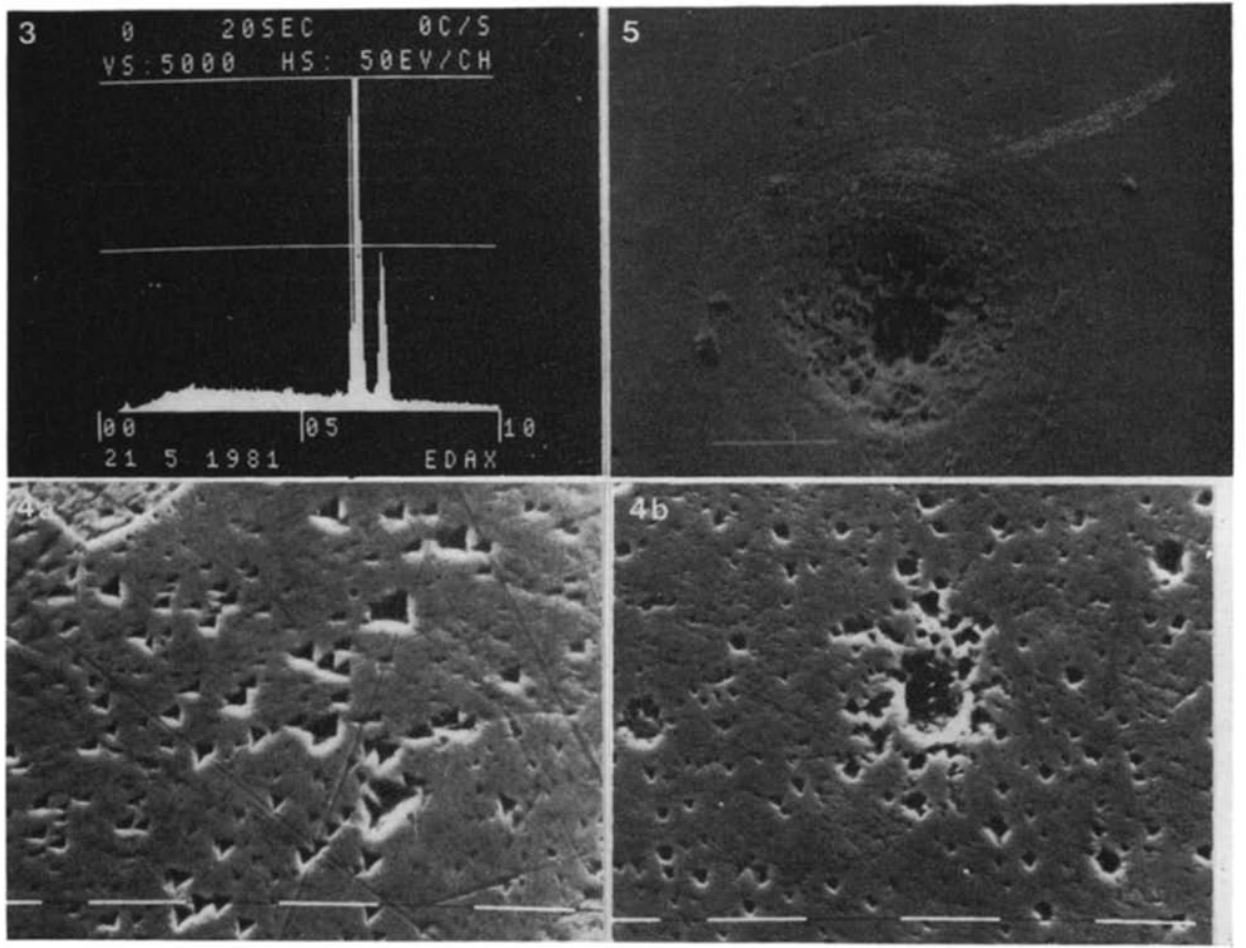

FIG. 3. Energy dispersive X-ray spectra of metal surface outside of the spots. No sulphur signal is observed $\left(10^{-2} \mathrm{M} \mathrm{Na} \mathrm{Na}_{2} \mathrm{~S} ; \mathrm{pH} 11.54 ; E-0.50 \mathrm{~V}, t 2\right.$ min $)$.

FIG. 4. (a) SEM microphotograph of crystallographic pits formed on mild steel at a constant potential in the transpassive region. (b) Transitions from the spike-type to hemispherical-type pits $\left(10^{-2} \mathrm{M} \mathrm{Na} \mathrm{N}_{2} \mathrm{pH} 11.54 ; t \quad 15 \mathrm{~min}, 1800 *\right)$.

FIG. 5. SEM microphotograph of a large pit showing the correlation with the blister morphology of the spot and its radial growth. $\left(10^{2} \mathrm{M} \mathrm{Na} 2 \mathrm{~S} \mathrm{pH} 11.54, E=-0.50 \mathrm{~V}, t\right.$ $30 \mathrm{~min}, 500 \%$ ). 


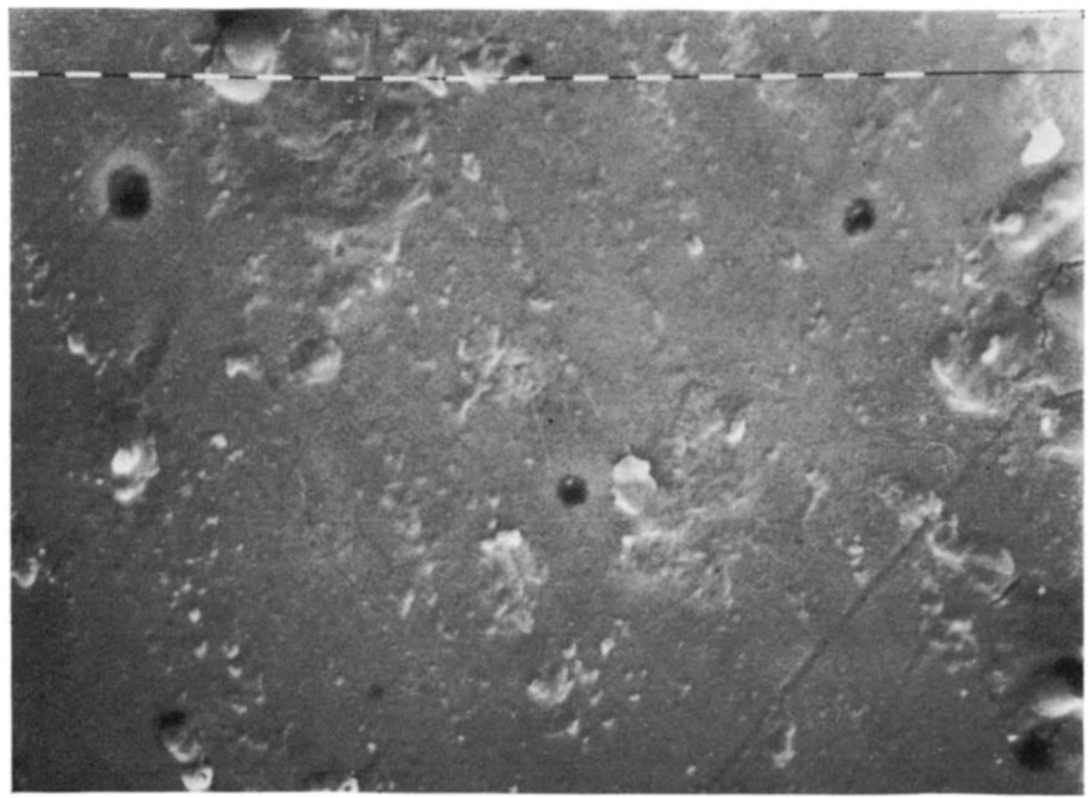

FIG. 6. SEM microphotograph of small pits formed in the active region $(E=-0.90 \mathrm{~V}$ during $30 \mathrm{~min}\left(10^{-2} \mathrm{M} \mathrm{Na}_{2} \mathrm{~S} \mathrm{pH} 11.54,3600 \times\right)$. 
patches of irregular shape. On increasing the contact time of the sample with the corroding medium at a constant potential the growth of the pits occurs in a definite crystallographic direction finally yielding a large pit in the central region of the blister (Fig. 5). Therefore, the SEM data show a correlation between both the blister and the pit structures. At the end, the whole electrode surface becomes covered with a thick layer of mackinawite and the underlaying metal shows a rough etched surface texture.

If the electrode potential is held at any value below the transpassive potential range, micropits can be detected which seem to be formed in the active dissolution region. Pits formed in $10^{-2} \mathrm{M} \mathrm{Na}_{2} \mathrm{~S}$ (pH 11.54) during $30 \mathrm{~min}$ at $-0.90 \mathrm{~V}$ (Fig. 6) are of irregular shape and their sizes arc not greater than $3 \mu \mathrm{m}^{2}$. Through the observation of the current behaviour and pit size distribution in this potential range it appears that these micropits are casily repassivated.

The current efficiency related to the electrodissolution process of steel in $10^{-2} \mathrm{M}$ $\mathrm{Na}_{2} \mathrm{~S}(\mathrm{pH} 11.54)$ was determined by holding the potential at $-0.45 \mathrm{~V}$ for $4 \mathrm{~h}$ by two independent methods, namely, by integration of $I /$ time transient and by the weight loss of the iron electrode. Both procedures gave an approx. $100 \%$ electrodissolution efficiency for the valency of dissolved iron to 2, on the basis that the main corrosion product is FeS. Obviously, these results discard any contribution to the anodic current due to the sulphide ion electro-oxidation. Therefore, almost all the current related to the transpassive region should be ascribed to the iron electrodissolution through the active pits.

In the solutions containing $10^{-2} \mathrm{Na}_{2} \mathrm{~S}$. in the $11.00<\mathrm{pH}<12.00$ range, the $\mathrm{pH}$ has a remarkable influence on the potentiostatic $E / I$ curves. As the $\mathrm{pH}$ decreases the anodic current peak associated with the active-passive transition is enhanced and the breakdown potential moves towards more negative values (Fig. 7). At pH 11.00

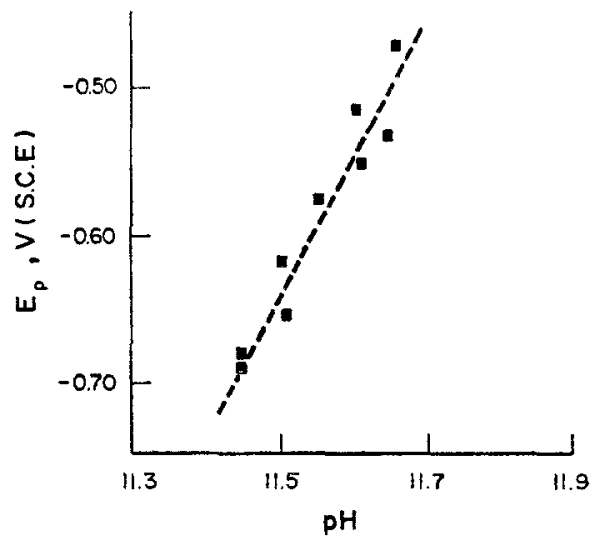

FIG. 7. Plot of the breakdown potential vs pH.

the curve shows only an inflection in the passivation potential region and the electrode surface becomes instantaneously covered with a layer of black corrosion product. At $\mathrm{pH} 12.00$ the pitting process is inhibited and a remarkable decrease in the rate of the electrochemical process is noticed at the positive potential side (Fig. 8). 


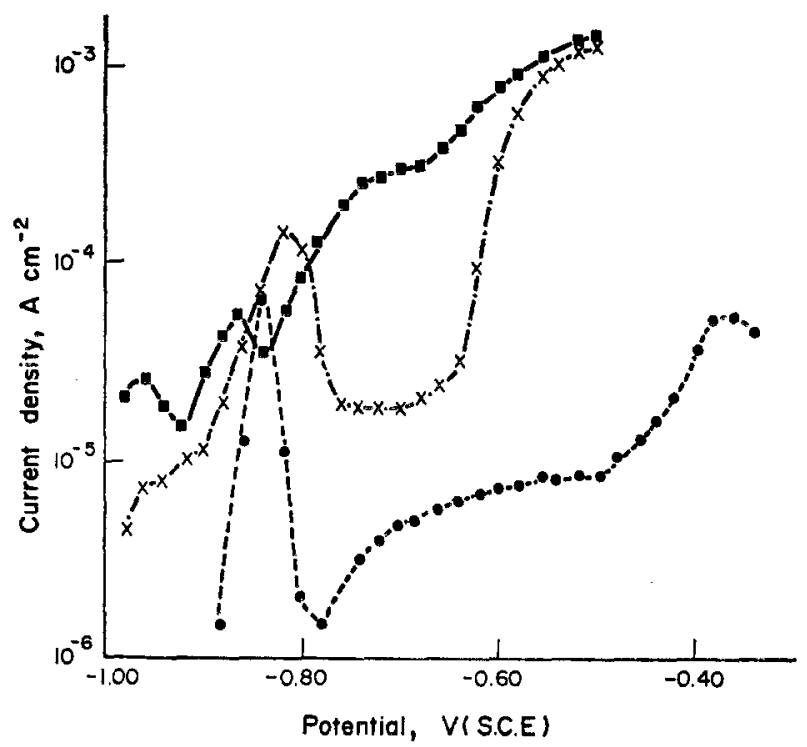

FIG. 8. Current/potential curves of mild steel in $10^{-2} \mathrm{M} \mathrm{Na}_{2} \mathrm{~S}$ at different $\mathrm{pH}$. $\mathrm{pH} 11.00$ ( $\mathbf{\square})$; pH $11.50(\times)$; pH $12.00(\bullet)$.

To obtain additional information about the inhibiting process observed at low $\mathrm{SH}-/ \mathrm{OH}^{-}$concentration ratios, voltammetric experiments were made in $2 \times 10^{-2} \mathrm{M}$ $\mathrm{NaOH}$ and $2 \times 10^{-2} \mathrm{M} \mathrm{NaOH}+10^{-2} \mathrm{M} \mathrm{Na}_{2} \mathrm{~S}$. During the first positive potential scan the corresponding RTPS $E / I$ display (Fig. 9a), between -1.40 and $0.00 \mathrm{~V}$, show three anodic current peaks at about $-1.05 \mathrm{~V}$ (peak I); $-0.85 \mathrm{~V}$ (peak II); $-0.53 \mathrm{~V}$ (peak III) and a poorly defined shoulder at $-0.40 \mathrm{~V}$ (peak III'). During the reverse scan, two current peaks located at $-1.07 \mathrm{~V}$ (peak IV) and $-1.20 \mathrm{~V}$ (peak V) are recorded. Current peak (IV) shows a cathodic contribution at the positive potential side (peak IV'). The following RTPS shows a gradual decrease in height of current peaks (I) and (II), an increase in height of both peaks (III), (IV) and (IV') and a decrease in height of current peak (V). Similar results have been previously described.12-14 Peaks (I) and (II) are related to the $\mathrm{Fe}(\mathrm{OH})_{2}$ formation while peak (V) corresponds to the conjugated reaction. The $\mathrm{Fe}(\mathrm{OH})_{2}$ species assigned to peaks (I) and (II) are electro-oxidized to FeOOH species ${ }^{15}$ in the second level (peaks III and III'). Later, this product is transformed into the most stable layer containing both $\mathrm{Fe}_{3} \mathrm{O}_{4}$ and hydrated $\mathrm{Fe}_{2} \mathrm{O}_{3} .{ }^{12}$ Peaks (IV) and (IV') correspond to the electroreduction of the film formed in the potential range of peaks (III) and (III'). The addition of sulphide $\left(10^{-2} \mathrm{M}\right)$ produces remarkable changes in the $E / I$ profile (Fig. 9b). During the first scan a large single anodic current peak appears in the potential range corresponding to peaks (I) and (II) in the $\mathrm{NaOH}$ solutions while peak (III) remains apparently unchanged. But at its positive potential side there is a greater current contribution whereas no appreciable change is noted for peak (IV). During the negative going potential scan, peak (V) shows a considerable increase in height. During the second positive going potential scan, the large anodic peak is revealed as a double current peak, the height of peak (III) decreases and a new current contribution appears in the $-0.30 \mathrm{~V}$ (peak VI). During the reverse scan an 


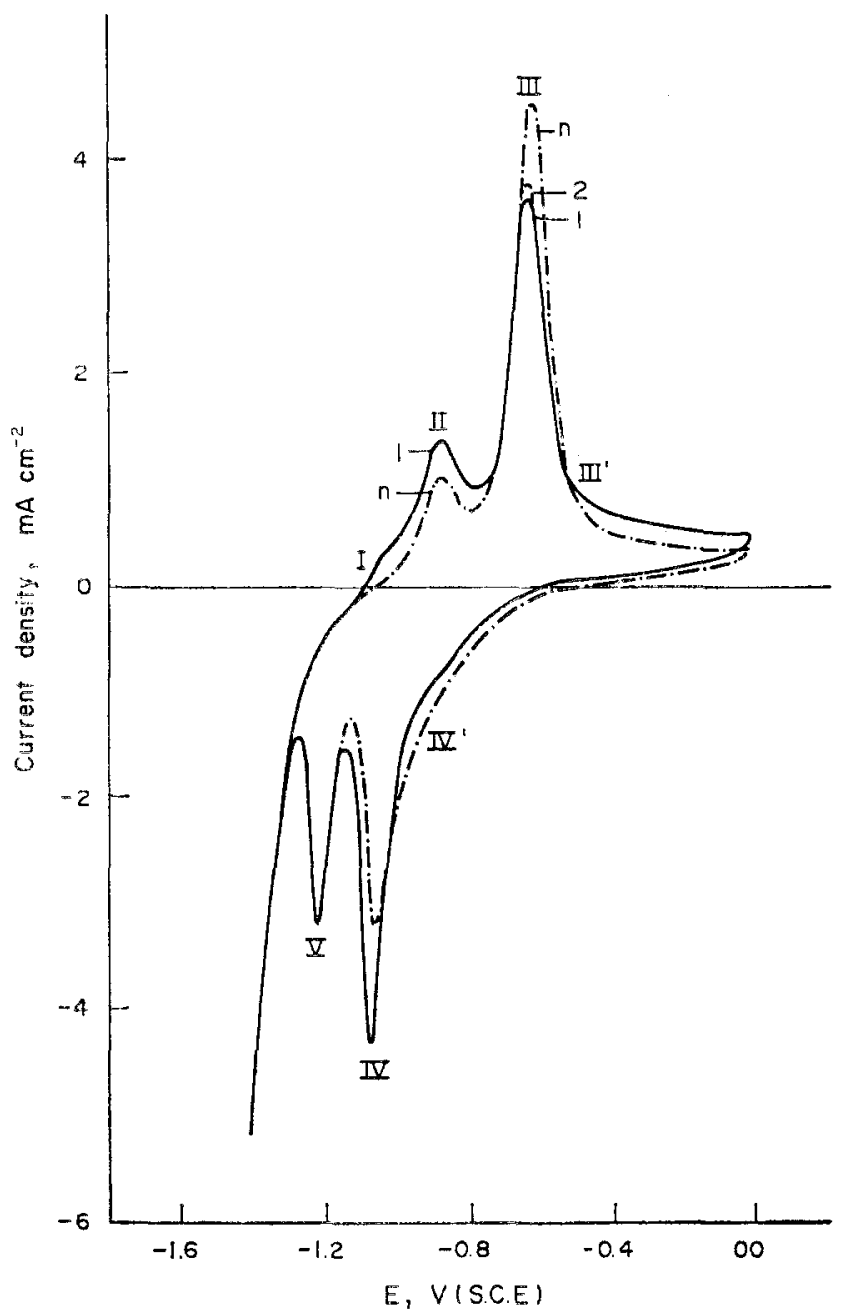

FIG. 9 (a).

increase in the height of peak (IV') is noticed. The voltammogram obtained after cycling the electrode during 40 min between -1.40 and $0.00 \mathrm{~V}$ at $0.020 \mathrm{~V} \mathrm{~s}^{-1}$ shows an increase of the anodic current peaks (I) and (II) while peak (III) gradually decreases in height. Despite this response the cathodic charge corresponding to peaks (IV) and (IV') increases showing that a certain amount of oxide is already formed in the potential region corresponding to peak (VI).

The kinetics of the potentiostatic pits growth in $10^{-2} \mathrm{M} \mathrm{Na}_{2} \mathrm{~S}(11.40<\mathrm{pH}<11.80)$ approaches the Engell-Stolica relation ${ }^{16}$ with an exponential coefficient equal to 3/2 (Fig. 10). This exponent is similar to that reported by Mankowski and SzklarskaSmialowska for pitting of stainless steel in solutions containing both chloride and sulphate ions. ${ }^{17}$ In this case, the pits are also covered by a film separating the solution inside the pit from the bulk solution. 


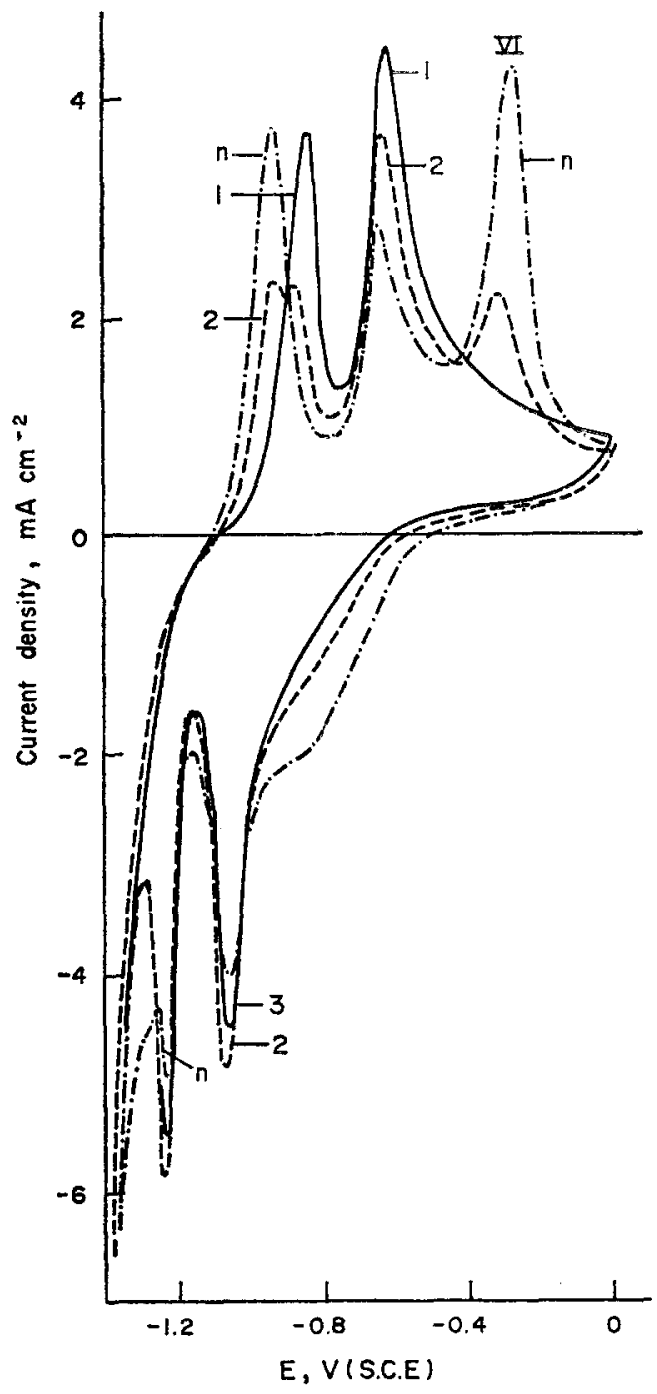

FIG. (9b).

FIG. 9. (a) Current/potential profiles (RTPS at $0.020 \mathrm{~V} \mathrm{~s}^{-1}$ ) obtained in $2 \times 10^{-2} \mathrm{M}$ $\mathrm{NaOH}$; (b) $2 \times 10^{-2} \mathrm{M} \mathrm{NaOH}+10^{-2} \mathrm{M} \mathrm{Na} 2 \mathrm{~S}$. (1) first potential sweep; (2) second potential sweep; (n) profile resulting after 40 min RTPS.

At a constant potential the current increases until the whole electrode surface is covered by a layer of mackinawite. At $\mathrm{pH}$ values lower than 11.40 , the initial current density is greater than that observed within the same potential range at $\mathrm{pH}$ values greater than 11.40 (Fig. 11). The initial current density remains constant for a few minutes later decreasing slowly with time. The large current value becomes possible because the initial mackinawite film seems to be highly stressed and cracks readily. ${ }^{4,8}$ However, the current decrease is due to the formation of a thick layer of mackinawite 


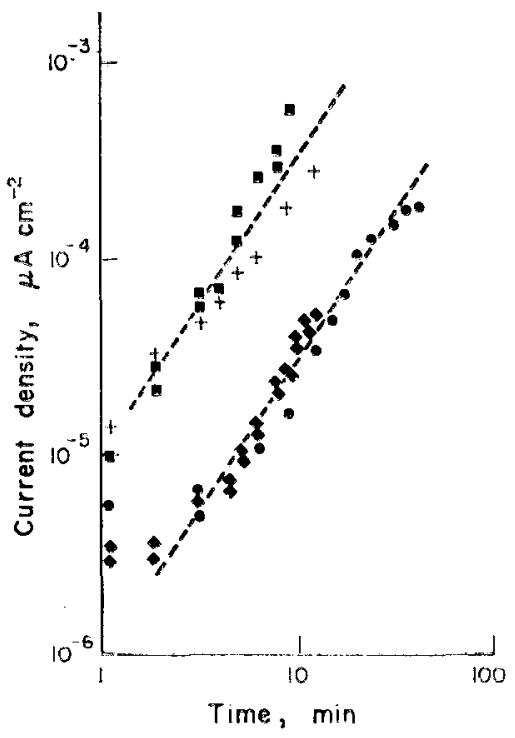

FIG. 10. Current/time records at a constant potential in the transpassive region. The specimens were prepassivated during $5 \mathrm{~min}$ at $-0.70 \mathrm{~V}$ and immediately held at $50 \mathrm{mV}$ above of the breakdown potential, $\mathrm{pH} 11.70(\$)$; $\mathrm{pH} 11.60(\bullet)$; $\mathrm{pH} 11.54(+)$; $\mathrm{pH} 11.40(\mathbf{a})$.

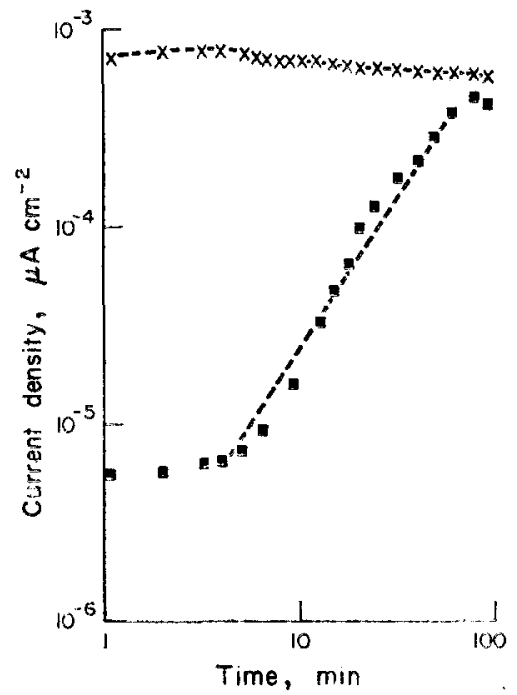

Fr. 11. Current/time records for mild steel in $10^{-2} \mathrm{M} \mathrm{Na} 5 \mathrm{st}-0.50 \mathrm{~V}$ in the transpassive region. pll $11.0(\times) ; \mathrm{pH} 11.60(\mathrm{~m})$.

covering all the electrode surface. When the relation $\mathrm{SH} / \mathrm{OH}^{-}$is low a protective film is formed and the pit growth is hindered.

Chemical reaction between iron powder and $10^{-2} \mathrm{M} \mathrm{Na} \mathrm{Na}_{2} \mathrm{~S}(\mathrm{pH} 11.54)$ yields both a soluble green product and mackinawite. Using the phenanthroline test reaction, $10^{-5} \mathrm{M}$ 
soluble iron concentration is found after $240 \mathrm{~h}$. No change in the soluble iron concentration was obtained either in the presence or in absence of hydroxylamine suggesting that iron is dissolved mainly as $\mathrm{Fe}^{2+}$. The total sulphide concentration remains constant during the experiment. The visible spectrum of the aqueous solution after the reaction is similar to that already described by Shoesmith et al. for the solution resulting after the pitting of iron in alkaline sulphide solutions. These spectra were interpreted through the formation of $\mathrm{NaFeS}_{2} \cdot{ }^{3,4}$ Similar results were obtained from the reaction between $\mathrm{FeS}$ and $10^{-2} \mathrm{M}$ sodium sulphide ( $\mathrm{pH} 11.54$ ) solution, but no reaction takes place with $\mathrm{Fe}_{2} \mathrm{O}_{3}$ powder under the same experimental conditions.

\section{DISCUSSION}

The breakdown of the passive film on iron in alkaline sulphide solutions has been attributed to the oxidation of $\mathrm{SH}^{-}$to elemental sulphur according to:

$$
\mathrm{SH}^{-} \rightleftharpoons \mathrm{S}+\mathrm{H}^{+}+2 \mathrm{e} .
$$

This reaction produces a substantial increase in the local concentration of protons around the oxide faults which results in a local attack of the oxide film and in the eventual initiation of metal pitting. ${ }^{3}$ The inhibiting effect observed at a low $\mathrm{SH}^{-} / \mathrm{OH}^{-}$ concentration ratio $(r)$ has been associated with a protective film of elemental sulphur ${ }^{3}$ which occurs either in the regions where the passive film rupture takes place or in the defects of the film or in both places at the same time. The continuity of attack depends on $r$ so that for small values of $r$, precipitated $S$ would block the surface of the metal; while for high values of $r$, the dissolution of $S$ as a polysulphide ion species is enhanced. ${ }^{4}$ The presence of $S$ on the metal would be indicated by a voltammetric cathodic current peak which practically overlaps the current peak related to the electroreduction of $\mathrm{Fe}(\mathrm{OH})_{2}$. Conversely, the present results show that when $r$ is low, by holding the potential in the region where pitting occurs, no evidence of the sulphur layer formation isfound, but only a few spots on the surface have been observed. ${ }^{3}$ Therefore, if one takes into account that the sulphide species are rapidly oxidized by $\mathrm{O}_{2}$ to $\mathrm{S},{ }^{9}$ the previous information seems to be not conclusive about the possible mechanism for the breakdown of the passive film on iron in alkaline sulphide solutions.

A different explanation of the behaviour of iron in alkaline solutions containing $\mathrm{SH}-$ anions, based on the fact that both species $\mathrm{SH}^{-}$and $\mathrm{OH}^{-}$attack simultaneously the metal surface can be advanced yielding, respectively, sulphide and oxide species. The initial stages of the reactions should involve a competitive adsorption of the different species. This would explain the coincidence of the cathodic current peak at $-1.20 \mathrm{~V}$ with that assigned to the $\mathrm{Fe}(\mathrm{OH})_{2}$, as well as the slight increase in the hydrated $\mathrm{Fe}_{2} \mathrm{O}_{3}+\mathrm{Fe}_{3} \mathrm{O}_{4}$ electroreduction charge observed in the corresponding voltammograms (Fig. 9b). When $r$ is large, the formation of sulphide surface species and pitting corrosion are observed. Under these circumstances a decrease in the cathodic current peak overlapping that assigned to the $\mathrm{Fe}(\mathrm{OH})_{2}$ electroreduction and the simultaneous appearance of a small cathodic charge in the potential region corresponding to the $\mathrm{Fe}_{2} \mathrm{O}_{3}+\mathrm{Fe}_{3} \mathrm{O}_{4}$ electroreduction are observed. ${ }^{4}$ These facts suggest that a small fraction of oxide is also formed, probably because of the poor protecting characteristics of the sulphide layer. The deposition of sulphur on the 
electrode according to reaction (1) should be discarded as being related to the initiation of iron pitting. Moreover, there is no chemical evidence that sulphide species can dissolve $\mathrm{Fe}_{2} \mathrm{O}_{3}$, but $\mathrm{FeS}$ dissolves in the presence of sulphide anions yielding soluble $\mathrm{Fe}^{2+}$ species.

The interpretation of the present results can, therefore, be rationalized with a different approach which is based on the occurrence of competitive adsorption processes at the iron surface and alternative electro-oxidation reactions involving the different adsorbed species. Thus, the explanation of the overall process can be given in terms of the following reactions:

(I) Competitive adsorption reactions:

$$
\begin{aligned}
& \left(\mathrm{H}_{2} \mathrm{O}\right) \mathrm{Fe}+\mathrm{OH}^{-}=\mathrm{Fe}\left(\mathrm{OH}^{-}\right)+\mathrm{H}_{2} \mathrm{O} \\
& \left(\mathrm{H}_{2} \mathrm{O}\right) \mathrm{Fe}+\mathrm{HS}^{-}=\mathrm{Fe}\left(\mathrm{SH}^{-}\right)+\mathrm{H}_{2} \mathrm{O}
\end{aligned}
$$

(II) Oxygen containing film formation:

$$
\begin{aligned}
& \mathrm{Fe}\left(\mathrm{H}_{2} \mathrm{O}\right)=\mathrm{Fe}(\mathrm{OH})+\mathrm{H}^{+}+\mathrm{e} \\
& \mathrm{Fe}(\mathrm{OH})=\mathrm{Fe}(\mathrm{OH})^{+}+\mathrm{e} \\
& \mathrm{Fe}(\mathrm{OH})^{+}+\mathrm{OH}^{-}=\mathrm{Fe}(\mathrm{OH})_{2} \rightarrow \text { passivating oxide layer } \\
& \mathrm{Fe}\left(\mathrm{OH}^{-}\right)=\mathrm{Fe}(\mathrm{OH})+\mathrm{e} \\
& \mathrm{Fe}(\mathrm{OH})=\mathrm{Fe}(\mathrm{OH})^{+}+\mathrm{e} \\
& \mathrm{Fe}(\mathrm{OH})^{+}+\mathrm{OH}^{-} \quad \mathrm{Fe}(\mathrm{OH})_{2} \rightarrow \text { passivating oxide layer }
\end{aligned}
$$

(III) Sulphur containing film formation:

$$
\begin{aligned}
& \mathrm{Fe}\left(\mathrm{SH}^{-}\right)=\mathrm{Fe}(\mathrm{SH})+\mathrm{e} \\
& \mathrm{Fe}(\mathrm{SH})=\mathrm{Fe}\left(\mathrm{SH}^{+}\right)+\mathrm{e} \\
& \mathrm{Fe}(\mathrm{SH})^{+}+\mathrm{HS}^{-} \rightleftharpoons \mathrm{FeS}+\mathrm{H}_{2} \mathrm{~S} \rightarrow \text { mackinawite }
\end{aligned}
$$

(IV) Equilibria involving sulphur containing species:

$$
\begin{aligned}
& \mathrm{Fe}(\mathrm{OH})^{+}+\mathrm{Fe}\left(\mathrm{SH}^{-}\right)=\mathrm{Fe}\left(\mathrm{SH}^{+}\right)+\mathrm{Fe}\left(\mathrm{OH}^{-}\right) \\
& \mathrm{Fe}\left(\mathrm{SH}^{+}\right)=\mathrm{Fe}^{2+}+\mathrm{HS}^{-}
\end{aligned}
$$

where the parentheses denote adsorbed species.

The set of reactions (I) represents the adsorption equilibria at the metal surface involving $\mathrm{H}_{2} \mathrm{O}, \mathrm{OH}^{-}$and $\mathrm{HS}^{-}$species. The set of reactions (II) involves the initial stages (IIa) and (IId) of the simplest mechanism for iron dissolution and passivating oxide film formation. ${ }^{20,21}$ Reactions (IIc) and (IIf) explain the formation of the 
passivating oxide layer. These reactions comprise the reaction pathways corresponding to the electrodissolution and passivation of iron in alkaline solutions in the absence of sulphide ions. ${ }^{11,22}$ The set of reactions (III) refers to the electro-oxidation of the sulphide covered metal and the formation of the mackinawite film. The set of reactions (IV) is favoured when the degree of surface coverage by $\mathrm{OH}^{-}$species is lower than that of the $\mathrm{SH}^{-}$ion species. In agreement with previous considerations, the mackinawite film formation is promoted at lower $\mathrm{pH}$ values. ${ }^{4}$ Reaction (IIIb) yields the intermediate species $\mathrm{FeSH}^{+}$which enter different equilibria as indicated by the set of reactions (IV). The species $\mathrm{FeSH}^{+}$should be responsible for the dissolution of the metal as $\mathrm{Fe}^{2+}$. Probably the $\mathrm{FeSH}^{+-}$species is stabilized in solution through the formation of a hydrosulphide complex. ${ }^{23}$

The proposed sequence of reactions can explain the morphology of the attack of iron in the alkaline sulphide solutions. Thus, the $E / I$ curves (Fig. 8) exhibit no passivation when the $\mathrm{SH}^{-}$concentration is much greater than the $\mathrm{OH}^{-}$concentration. This suggests that under these circumstances the set of reactions (III) and (IV) are favoured. Then, a mackinawite layer is instantaneously formed on the clectrode and the metal surface attack is mainly uniform. This is in agreement with the well-known fact that the mackinawite film is the least protecting iron sulphide as it permits a rapid diffusion of $\mathrm{Fe}^{2+}$ and hence high corrosion rates. ${ }^{17,24}$ This film is probably formed through a dissolution precipitation mechanism involving in part reaction (IVb). When the $\mathrm{SH}$ concentration is greater than $\mathrm{OH}^{-}$concentration the occurrence of the set of reactions (II), (III) and (IV) yields an oxide film with sulphide species located at certain sites of the metal surface which, at a given potential, become nucleation centres for the iron pitting. Finally, when the $\mathrm{SH}^{-}$and the $\mathrm{OH}^{-}$concentrations are approximately alike, reactions (I) and (II) predominate and either the metal passivation or repassivation is then favoured.

In the present work it is found that the mackinawite spots on the surface are of the blister-type so that the EDAX analysis of the broken blisters on the metal surface reveals no sulphur in the centre of the spot. Accordingly, it appears that each pit is covered by a blister-like FeS film, so that the FeS is mainly located at the shell of the blister in contact with the bulk electrolyte. Therefore, after the blister is blown up, the FeS-species locates at the border of the blister base, in correspondence with the sulphur composition profile found by EDAX. This suggests that probably the FeS precipitates by a chemical reaction at a certain distance from the place where the metal electrodissolution was initiated. This explanation agrees with the fact that the ionic concentration gradients which are established within the pit ${ }^{25}$ assist the mackinawite precipitation at the outer periphery. This would interpret not only the blister formation process but also the poor adherence of the film to the base metal. From the preceding discussion it is concluded that the rate and type of blister growth should be more likely related to the current of pit nucleation and growth than to the nucleation of film centres as recently postulated. ${ }^{4}$ y Técnicas, Universidad Nacional de La Plata and the Comisión de Investigaciones Científicas de la Provincia de Buenos Aires. 


\section{REFERENCES}

1. P'. W. Bolmer, Corrosion 21, 69 (1965).

2. M. J. BOuET, Cr. 236, 1973 (1963).

3. D. W. Shoesmith, M. G. BALEY and B. IKeDA, Electrochim. Acta 23, 903 (1978).

4. D. W. Shoesmith, M. G. Baley and B. IKedA, Electrochim. Acta 23, 1329 (1978).

5. D. Tromans, J. electrochem. Soc. 127, 1253 (1980).

6. D. A. Wensley and R. S. Charlton, Corrosion 36, 385 (1980).

7. H. KAESCHE, Werktoffe. Korros. 21, 185 (1970).

8. M. JANIK CZaChOR and E. Reiche, Werktoffe Kurros. 27, 5 (1976).

9. K. OGURA, J. electroanal. Chem. 79, 149 (1977).

10. A. I. VoGeL, Quantitative Inorganic Analysis, Longmans, Green, London (1947).

11. C. B. BARgeron and R. B. Givens, Corrosion 36, 618 (1980).

12. R. S. Schrebler Guzmán, J. R. Vilche and A. J. Arvía, Electrochim. Acta 24, 395 (1979).

13. D. D. MACDONALd and B. RoBerts, Electrochim. Acta 23, 781 (1978).

14. D. Geana, A. A. El Miligy and W. J. Lokenz, J. appl. Electrochem. 4, 337 (1974).

15. L. OJEFORS, J. electrochem. Soc. 123, 1694 (1976).

16. H. J. ENGell and N. D. Stolica, Z. phys. chem. Unerr. 20, 113 (1959).

17. J. Mankowski and Z. SzKLaRSKa-Smialowska, Corros. Sci. 12, 925 (1972).

18. A. J. Wikjord, T. E. Rummery, F. E. Doern and D. G. Owen, Corros. Sci. 20, 651 (1980).

19. H. G. OstLund and J. AleXANDER, J. geophys. Res. 68. 3995 (1963).

20. J. O’M. Bockris, M. Genshaw and V. Brusic, Symp. Furaday Soc. 4, 177 (1970).

21. J. O'M. Bockris, A. K. N. Reddy and B. RaO, J. electrochem. Soc. 114, 1133 (1966).

22. J. R. Vilche and A. J. Arvía, Acta Cient. Venez. 31, 496 (1980).

23. G. Schwarzenbach and M. Widner, Helv. chim. Acta 46, 2613 (1963).

24. D. W. Shoesmith, T. E. Rummery, M. G. Baley and D. G. OWEN, J. electrochem. Soc. 126, 911 (1979).

25. J. R. Galvele, J. electrochem. Soc. 123, 464 (1976). 